\title{
Genetic Regulation of Recurrent Spontaneous Abortion in Humans
}

\author{
Daniel Vaiman
}

\begin{abstract}
Recurrent pregnancy loss, defined as a pregnancy failure occurring before 24 weeks of gestation more than two or three times according to most definitions, is a fertility defect encountered in 1-5\% of the patients. This defect is of course of multifactorial origin. Among the possible origins of recurrent pregnancy loss are uterine structural defaults, defective ploidy control of the embryo, defective immunological dialog between the embryo (or the fetus) and the uterus sometimes in relation with immunological disorders (such as autoimmune diseases), thrombophilia, and free radical metabolism imbalance. Numerous studies attempted to correlate variants of genes supposed to be intervening in the different facets of the early maternal-fetal or maternal-embryonic dialog, and eventually modify the outcome

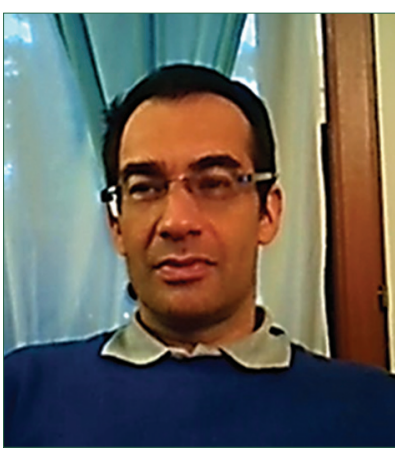

Dr. Daniel Vaiman of fertilization, leading to success or failure of post-implantation development. The objective of the present review is to portray the major genes and gene polymorphisms studied for their putative association with recurrent pregnancy loss. Most of these genes have been studied as candidate genes for which strong biological arguments were put forward as to their putative involvement in recurrent pregnancy loss. They were mostly studied by genetic analysis, often in various populations of different ethnic origins, throughout the world. Some of these studies were available only in English as abstracts and were nevertheless used if the information was given with enough detail. With the space being too short to depict all the available literature, different major pathways releva nt to the scientific question are presented without any attempt to hide the fact that discordant views often aroused for a given gene. (Biomed J 2015;38:11-24)
\end{abstract}

\section{Key words: genetics, infertility, recurrent miscarriage}

$\mathrm{I}^{\mathrm{n}}$ humans, pregnancy may be interrupted at various stages, leading to abortion, and this process occurs repetitively in some patients. Repetitive interruptions of pregnancy are variously referred to as recurrent spontaneous abortion (RSA), recurrent pregnancy loss (RPL), recurrent miscarriage (RM), idiopathic recurrent miscarriage (iRM), or unexplained recurrent spontaneous abortion (URSA). These different terms indicate terminations of pregnancy occurring more than 2 times for a given patient, before 24 weeks of gestation, in most definitions of the syndrome. In humans, it appears that at least $15 \%$ of the recognized pregnancies end in miscarriage. In an estimated half of the cases, chromosomal anomalies such as aneuploidies are observed. ${ }^{[1]}$

In this review, we will attempt to summarize current knowledge on the genetic basis of recurrent abortions, and will not deal with environmental or stochastic factors that can lead to isolated abortive events. Clearly, for instance, the increase of chromosomal anomalies leading to aneuploidy and mosaicism in blastocyst ${ }^{[2]}$ is generally associated with mother's age (even though paternal age may also be considered as a risk factor $)^{[3]}$ and is beyond the scope of the present review. However, genetic defects leading to a quasi-systematic increase of aneuploidy will be considered. Other possible genetic causes of recurrent abortion may be found in developmental defects of the blastocyst or the embryo that do not involve gross chromosome anomalies, but probably much more frequently involve a defective materno-fetal immunological dialog, or a defective uterine function impeding early development. There is a plethora of articles dealing with genetic polymorphisms associated with RSA. However, until now, the genetic polymorphism analysis has been concentrated on a limited number of genes. We will not attempt to review exhaustively the existing literature, which analyzes various populations worldwide, but

From the Cochin Institute, U1016-INSERM, UMR8104 CNRS, Paris Descartes University, Paris, France

Received: Mar. 31, 2014; Accepted: May 20, 2014

Correspondence to: Dr. Daniel Vaiman, Institut Cochin, U1016-INSERM, UMR8104 CNRS, Université Paris Descartes. 24 rue du faubourg St. Jacques, 75014 Paris, France. Tel.: 33-1-44412301; Fax: 33-1-44412302; E-mail: daniel.vaiman@inserm.fr

DOI: $10.4103 / 2319-4170.133777$ 
rather attempt to categorize the factors that were analyzed according to their biological functions and summarize their putative effects.

\section{CANDIDATE GENE APPROACHES}

\section{Feto-placental side}

\section{Genetic bases of defective chromosome content or structure}

In a biological sense, genetic defects leading to abortion may originate from two partners: The conceptus and the uterus. From the conceptus side, it is well-established that chromosomal anomalies lead to implantation defects. However, they occur mostly stochastically; to be the genetic cause of a recurrent loss, a genetic defect leading to systematic chromosome anomalies has to be found, as nicely reviewed recently by Kurahashi and coworkers. ${ }^{[4]}$ Abnormal chromosome structure may originate from defects in the checkpoint mechanisms that constitute a quality control factory of the cell, which is able to detect meiosis anomalies and is called Spindle Assembly Checkpoint (SAC), constituted by proteins such as Mad1, Mad2, Bub1, Bub3, BubR1, and Mps1. [5] A very recent study addressed this question on the general issue of defective reproduction performance, by screening two candidate genes, aurora kinase $\mathrm{B}(A U R K B)$ and synaptonemal complex protein 3 (SYCP3). In the AURKB gene, the authors identified low-frequency $(0.5 \%)$ non-synonymous variants (c. 155C.T, c. 236T.C, and c. 880G.A) inducing the changes p.A52V, p.I79T, and p.A294T in the polypeptidic chain, respectively. 236T $>\mathrm{C}$ and $880 \mathrm{G}>\mathrm{A}$ were associated with antecedents of pregnancy losses. ${ }^{[6]}$ This preliminary study is one of those that pave the way toward evaluating genes playing a role in the quality of the meiotic progression. Two other genes have been investigated to this respect in miscarriage, $B U B 1$ and MAD2. ${ }^{[7]}$ The authors showed firstly that as generally assumed, half the embryos from spontaneous miscarriages have an abnormal karyotype. By western blotting, the authors quantified the two proteins and estimated that they were under-expressed in pathological cases. The authors also isolated chorionic villi where they targeted $B U B 1$ and $M A D 2$ expression by short hairpin RNA (shRNA) and showed that this induces an abnormal karyotype at a sixfold increased frequency, compared to controls (indicating that mitotic defects can also be induced when these genes are dysfunctional). The role of MAD2 in such defects was independently confirmed by another study on trisomic abortuses.$^{[8]}$ Clearly, therefore, anomalies in spindle assembly can lead to aneuploidies, and infertilities in the most severe cases, such as in the case of the recently identified mutation of the cohesin STAG3, leading to premature ovarian failure, ${ }^{[9]}$ but less severe mutations in the $S A C$ genes could lead to variants that have more subtle effects. There is clearly space for studying this aspect of spindle stability on a wider basis than what has been performed up to now in the context of recurrent miscarriage.

\section{Placental developmental defects}

The mammalian placenta plays several crucial roles in the initiation and maintenance of pregnancy. In humans, it constitutes the main immunological interface between mother and child, allowing tolerance between two genetically distinct organisms. It is the major exchange surface between the two; at the end of pregnancy, $600 \mathrm{ml}$ of maternal blood circulates through the placenta at each minute. Finally, it secretes important hormones such as the human chorionic gonadotrophin (hCG) and the human placental lactogen (hPL) that have immunotrophic functions. In humans, the functional unit of the placenta is the placental villus, a densely branched tree (up to 16 ramification levels), covered by a syncytium, the syncytiotrophoblast. ${ }^{[10]}$ Normally, there is an intimate relation between the endometrium and the invasive human placenta; therefore, it can be suspected that at least in some cases, defective invasion can be caused by genetic specificities of the placenta and may lead to abortion.

In a recent study of Lyu and coworkers, ${ }^{[11]}$ the authors investigated the placental villi in the cases of idiopathic miscarriages, comparing four controls and four miscarriages with expression microarrays, after collecting the villi at 10-12 weeks. In this study, the authors uncovered essentially modifications in the management of oxidative stress, and more specifically, in glutathione metabolism. Glutathione depletion leads to accumulation of superoxide radicals that play a toxic role in the cells $;^{[12]}$ indeed, glutathione peroxidases are the only enzymes able to manage $\mathrm{H}_{2} \mathrm{O}_{2}$ in the mitochondrial context (since catalase is not expressed in the mitochondria), and require reduced glutathione (GSH) to convert $\mathrm{H}_{2} \mathrm{O}_{2}$ into water. ${ }^{[13]}$ As well, genes involved in mitochondrial function, especially oxidative phosphorylation, appeared affected. These results concur with several reports linking oxidative stress and recurrent miscarriage ${ }^{[14,15]}$ Consistently, the genetic background of the patients was recently explored, ${ }^{[16]}$ and revealed that $A B C B 1$, $C O M T, G P X 4$, and $O G G 1$ present single-nucleotide polymorphisms (SNPs) that are collectively associated with a 1.97 fold increased risk [confidence interval (CI): 1.31-2.97] of recurrent miscarriage. In the latter study, the genes were genotyped in the mother, which is responsible for only half of the genetic anlagen of the fetus. Nevertheless, it suggests that oxidative stress and free radical metabolism defects are linked to recurrent abortion.

More and more interest is now shown on the relations between oxidative and nitrosative stress in the field of re- 
production, ${ }^{[17,18]}$ albeit this issue was apparently not yet systematically explored in RSA. One of the important chemical intermediates for nitrosative stress is the peroxynitrite ion, $\mathrm{ONOO}^{-}$, which results from combining free oxygen species with nitric oxide (NO). NO is considered as a major vasodilator molecule, and plays even a crucial role in maintaining vascular health, especially in the context of pregnancy. ${ }^{[19]}$ $\mathrm{NO}$ is produced from l-arginine by NO synthases (NOS). Several studies analyzed the polymorphisms of endothelial nitric oxide synthase (eNOS) in recurrent pregnancy losses. A meta-analysis based upon 18 case-control studies, published in 2011, ${ }^{[20]}$ concluded that the Glu298Asp variant of eNOS was indeed associated significantly, albeit moderately, with RSA [odds ratio (OR): 1.37, CI: 1.11-1.69], this significance being observed only when dominant model was used. This masks a strong variation in the studies. For the present review, we screened 10 studies on eNOS published from 2001 to 2011, but focusing sometimes on polymorphisms other than Glu298Asp. Five studies concluded to an effect, ${ }^{[21-25]}$ while five concluded to no effect. ${ }^{[26-30]}$ It is well known that such discrepancies frequently occur in association studies, and clearly, meta-analysis cannot always substitute well-conducted experimental analyses with a sufficient statistical power. ${ }^{[31]}$ To explain the differences observed in the case of eNOS (but it applies equally well to other polymorphisms), one possibility could be related to the geographic origin of the various studies: Amongst the five positive ones, two are from India, one from Korea, one from China, and only one concerns a Caucasian population (Austria ${ }^{[21]}$ ). By contrast, the five negative studies are from Greece, Tunisia, Japan, Germany, and Austria and are, therefore, composed of Caucasian populations except the Japanese study. In the 10 studies that we screened, it is also noticeable that on average, the negative studies were smaller (cases $174 \pm 104$, controls $120 \pm 53$ ) than the positive ones (cases $186 \pm 93$, controls $169 \pm 84$ ), which may contribute to losing detection power.

\section{Maternal side}

\section{Hyperimmune reactivity}

The idea of the existence of strong links between immunity and reproduction is old, and nurtured by the fact that the fetus expresses paternal antigens that should be the target of graft-rejection mechanisms. Several theories have been proposed to explain the mere biological possibility of the pregnancy. ${ }^{[32,33]}$ The links between major histocompatibility complex (MHC) haplotypes and graft rejection has been clearly established long ago. ${ }^{[34]}$

\section{Autoimmune diseases}

The presence of autoantibodies is often associated with an increased risk of pregnancy loss. ${ }^{[35]}$ This issue has been recently extensively reviewed. ${ }^{[36]}$ The group of Yehuda Shoenfeld showed a significant increase of several autoantibodies in patients with RSA. ${ }^{[37]}$ Amongst other cues linking autoimmunity and pregnancy failure, it is interesting to quote the work of Mecacci and coworkers that explored the links between the detection of thyroid autoantibodies in the plasma and RSA. They analyzed a group of 69 patients (who were pregnant at least 6 months before the study, consisting of 29 RSA, 22 fetal deaths, and 18 preeclampsias), in comparison with a control group of 69 nonpregnant women, matched for age, parity, and gravidity. There was more than threefold increase in antithyroid autoantibodies in RSA patients compared to controls. Results on mice indicate that the detrimental link discovered in these patients may be disconnected from a direct action on major relevant tissues for pregnancy (such as placenta, decidua, or ovary) where the thyroglobulin gene is not strongly expressed. ${ }^{[38]}$

Once the links between autoimmunity and pregnancy failure are established, since this review focuses on genetics, the major issue is to collect relevant information on genetic variants leading to an increased risk of autoimmune reactions that could influence pregnancy maintenance. One exemplary study making this link is provided by a work published in 2011 by Salmon and coworkers. ${ }^{[39]}$ In this study, a cohort of 250 patients suffering from systemic lupus erythematosus (SLE) or expressing antiphospholipid antibodies (APL Ab) was analyzed with respect to genes of the complement cascade, since complement modifications have recurrently been shown to deregulate the angiogenic balance in the placenta. ${ }^{[40]}$ Amongst these patients, $17 \%$ suffered from preeclampsia (roughly threefold more than expected in the general population). While pregnancy loss was not the principal topic of the study, there are very strong cues to the idea that preeclampsia and pregnancy loss share common genetic bases, especially due to alleles increasing the risk of thrombophilia (see below).$^{[41,42]}$ In the last study, comparing 279 thrombophilic patients to 796 control patients, it was shown in thrombophilic patients (i.e. harboring risk alleles for coagulation factors $F 5$ rs6025 and F2 rs1799963) that treatment with low-molecular-weight heparin (LMWH) during a new pregnancy attempt decreased the risk of fetal death recurrence and preeclampsia simultaneously.

In the Salmon study of 2011, which mainly focused on complement factors and preeclampsia, mutations in $M C P$ and CFI were found to be increased in patients. The complement is classically considered to act along two major pathways (classical and alternative) [Figure 1]. Both pathways induce the hydrolysis of $\mathrm{C} 3$ into $\mathrm{C} 3 \mathrm{a}$ and $\mathrm{C} 3 \mathrm{~b}$. The latter cleaves C5 into C5a and C5b, leading eventually to formation of the membrane attack complex (MAC). Membrane cofactor protein (MCP) and complement factor I (CFI) are cofactors of the system: MCP is a transmembrane protein and CFI is a serine protease able to cleave and inactivate 


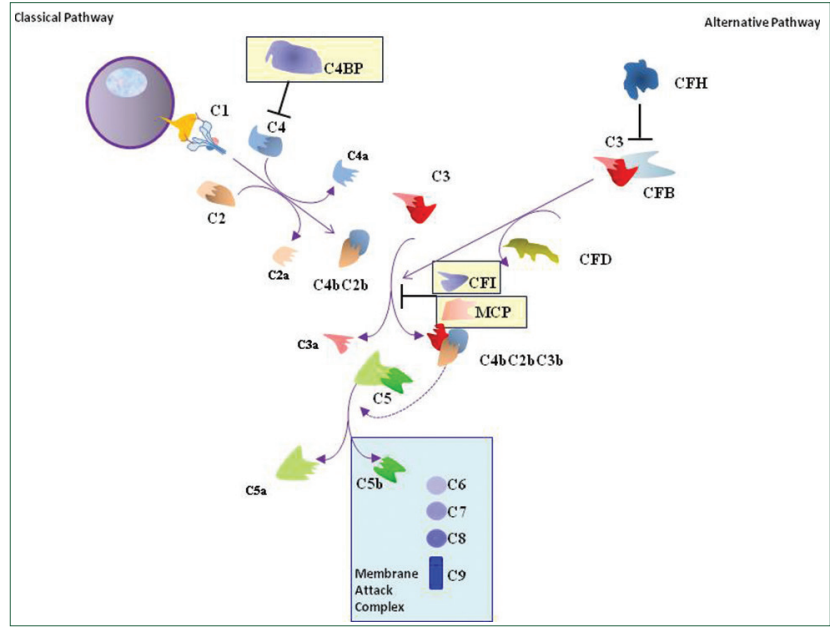

Figure 1: A simplified picture of the two major pathways of the complement cascade (the lectin pathway is not represented). In yellow boxes are presented the genes that have been analyzed for their putative impact on RSA through genotyping populations and that are discussed in this review. Interestingly, the polymorphisms that were studied generally concern genes having an inhibitory action on the complement cascade.

$\mathrm{C} 3 \mathrm{~b}$ and $\mathrm{C} 4 \mathrm{~b}$ that are needed for further steps leading to the final constitution of the MAC. MCP A304V corresponds to a variant displaying 50\% reduced activity in the control of $\mathrm{C} 3 \mathrm{~b}$ deposition by the alternative pathway. ${ }^{[43]}$ In addition, and in direct link to RSA, the authors discovered a mutation (K32N) in MCP in an SLE patient with RSA and preeclampsia. This mutation induces a $50 \%$ decrease in $\mathrm{C} 4 \mathrm{~b}$ binding, compared to wild type. This variant also induces a decreased CFI-mediated cleavage activity on $\mathrm{C} 4 \mathrm{~b}$. MCP, also known as CD46, had been tested in RSA genetic studies as early as in 1991 using the restriction fragment length polymorphism (RFLP) approach. ${ }^{[4]}$ In 1992, a study from Finland, using RFLP as well, discovered associations between $\mathrm{C} 4$ variants and tumor necrosis factor (TNF) variants with an increased risk of RSA. ${ }^{[45]}$ Since the two genes are separated by $\sim 400 \mathrm{~kb}$, it is improbable that the authors discovered a mere effect of linkage disequilibrium (LD), but rather a process where the two genes are independently involved through their specific functions in regulating complement/coagulation cascades (case of $\mathrm{C} 4$ a polymorphisms) and inflammation (in the case of TNF). The same team published in 1992 a study on 58 RSA couples, which did not reveal significant association with TNF variants, strengthening the idea of a necessary allelic association between $\mathrm{C} 4$ and TNF variants to observe a strong phenotype ${ }^{[45]}$ More recent studies carried out in India concur with the idea that MCP/CD46 is a genetic risk factor for abortion, ${ }^{[46]}$ but again with a limited sample (44 patients). A contradictory study was published in 2011 based upon a larger population (75 RSA and 115 controls), which could not put in evidence an effect of the A304V mutation. More recently, a genetic analysis of three complement pathway inhibitors, MCP/CD46, CD55, and C4 binding protein (C4BP), based on systematic exon sequencing of these factors was performed. ${ }^{[47]}$ Overall, 192 patients and 192 controls were sequenced in this thorough study. A heterozygous, non-synonymous mutation was found in C4BPB and some others in C4BPA (R240H), previously shown to decrease the co-factor activity of C4BP in degrading C3b. All the variants of C4BP were studied in vitro to evaluate their capacity of modulating the degradation of $\mathrm{C} 3 \mathrm{~b}$ and $\mathrm{C} 4 \mathrm{~b}$, showing an important reduction of these biochemical capabilities compared to the wild type variant when the R120H variant was used, as well as significant effects of I126T and I224T.

\section{“Wrong” HLA programming}

The human MHC system or human leukocyte antigen (HLA) is the "identity card" of humans. ${ }^{[48]}$ It is divided into three groups of genes on chromosome 6 called Class I (HLA-A, -B, -C, -E, -F, -G), Class II (HLA-DP, -DQ, DR, -DM, -DO), and Class III (including the TNF and other genes encoding proteins involved in inflammatory processes). A long time ago, it was shown that the placental structures do not present the same MHC molecules than the rest of the body and that increased homozygosity in mothers lead to pregnancy disorders, ${ }^{[49,50]}$ supposedly by decreasing the chances of allele sharing with the father ${ }^{[51]}$ As early as in 1992, Takakuwa and coworkers analyzed HLA-DQ antigens by polymerase chain reaction (PCR)-RFLP. This early exploration did not yield significant results, ${ }^{[52]}$ but did not discourage further efforts in investigating this issue. In fact, the Takakuwa team did later find associations between specific DR alleles (DRB1*0403 and DRB1*0410, and later DRB1*1502) and DQ alleles with recurrent miscarriage. ${ }^{[53]}$ Later on, similar increased risks were associated with specific DP alleles, such as DPB $1 * 04 .{ }^{[54,55]}$ By contrast, DP alleles appeared not to have a significant effect in the study of Sagot and coworkers. ${ }^{[56]}$ In 1992, Christiansen and coworkers genotyped DR and DQ by RFLP on 152 patients with RSA and 210 controls from Denmark, and concluded to a significant effect of specific genotypes such as DRw17, DQw2, as well as other specific DQ genotypes. ${ }^{[57-59]}$ Similar involvement of the MHC Class II genes was confirmed in 1993 in the Finnish population. ${ }^{[60]}$ More recent studies in Chinese patients suggest that some DQ alleles are risk factors as well. ${ }^{[61-63]} \mathrm{A}$ recent study confirmed the involvement of HLA-DR and -DQ variants to be associated with increased RSA risk in the Brazilian population. ${ }^{[64]}$ Therefore, the association of specific Class II MHC alleles with increased miscarriage seems quite robust. Overall, unfortunately, mechanistic insights from these abundant genetic/epidemiological data are absent.

For Class I genes, this absence of mechanistic ideas on the biological variant function is not totally similar, 
at least for HLA-G, referred to as an immunosuppressive molecule, ${ }^{[65]}$ and for which several polymorphisms were associated with RSA, as reviewed by Dahl and coworkers. ${ }^{[66]}$ HLA-G belongs to the subclass Ib, encompassing HLA-E, HLA-F, and HLA-G, and is highly expressed on trophoblast cells, which are much less polymorphic than the Class I genes [HLA-A and HLA-B are present in all the tissues except on the trophoblast cells, while HLA-C is expressed at a low level on the trophoblast and has indeed been associated with pregnancy disorders, such as preeclampsia and miscarriage, depending on the allelic complement of the killer cell inhibitory receptor (KIR) harbored by the maternal uterine Natural Killer (uNK) cells]. ${ }^{[67,68]}$ A very interesting feature of HLA-G is that upon specific alternative splicing events, the soluble forms HLA-G5, HLA-G6, and HLA-G7 are released and may play a long-range immunomodulatory function. HLA-G is now considered as a reliable marker of the success of in vitro fertilization (IVF). ${ }^{[69]}$ In 1997, HLA-G was tested to see if it was playing a role in the materno-fetal immunological dialog, but without taking into account any specific polymorphism. ${ }^{[70]}$ In 1999 , a consistent study evaluating the impact of an intron 4 polymorphism was published by Yamashita and coworkers. ${ }^{[71]}$ A non-synonymous substitution in exon 4 did not display significant correlations with pregnancy disorders. ${ }^{[72]}$ Nevertheless, the situation with regard to HLA-G started to change with a study using sophisticated mathematical tools and suggesting strongly that further investigation on HLA-G involvement in RSA was needed. ${ }^{[73]}$ In 2002, a Scandinavian study focused on a 14-bp polymorphism present in the $3^{\prime}$ UTR of the gene (generating an Ins/Del in the non-translated $8^{\text {th }}$ exon) and found that, curiously, in RSA couples, the 14-bp deletion was more abundant in men while the 14-bp insertion was more abundant in women. ${ }^{[74]}$ Later, the same team showed that the homozygous presence of the 14-bp sequence of exon 8 in women was significantly associated with infertility, combining the risk of unsuccessful IVF treatments and of RSA, when the two phenotypes were considered together. ${ }^{[75]}$ On the contrary, a study of Indian patients revealed an increase of $+14 \mathrm{bp} / 14 \mathrm{bp}$ heterozygotes in RSA women, and in another study, some significantly different haplotypes in terms of frequency between the two groups of women were observed. ${ }^{[76]}$ In a more recent article, paternal lymphocyte alloimmunization therapy (PLAT) was positively evaluated for treating $42 \mathrm{RSA}$ patients. Thirty-eight became pregnant in the following year and 27 babies were born. Interestingly, a $100 \%$ presence of HLA-G*010401 was seen in the 11 abortion cases, while it was present in only $51.9 \%$ of the cases that were a success. ${ }^{[77]}$ In 2006, a Chinese team could not find the association between HLA-G and RSA; $;^{[78,79]}$ also, a Polish study failed to do so, ${ }^{[80]}$ albeit the team suggested that nonsignificance was probably due to the small sample size. ${ }^{[1]}$ Two other negative studies were published - one in 2010 that analyzed 143 RSA and 150 control couples in the Indian population ${ }^{[82]}$ and another one in 2012 on an Iraqi population of $50 \mathrm{RSA}$ and 50 control women. ${ }^{[83]} \mathrm{By}$ contrast, Xue et al. discovered an excess of heterozygotes in Chinese RSA women, ${ }^{[84]}$ while another more recent study from China indicated an increased number of +14 bp homozygotes in the RSA women. ${ }^{[85]}$ Near the 14-bp Ins/Del, two polymorphisms (T1570VC and C1594A) were detected and found to be associated with RSA risk; ${ }^{[86]} \mathrm{T} 1570 \mathrm{C}$ was in LD with the cases but not with the controls. Other LD in the Class I region were shown. ${ }^{[87]}$ The comprehensive analysis of HLA-G sequence in the context of RSA was carried out by systematic sequencing of 238 cases and 233 RSA in Caucasian women. Twelve SNPs differed between the two groups of patients, while the authors also confirmed the increased risk brought by the 14-bp insertion. ${ }^{[88]}$ This concurred with the results of two Brazilian studies, the first one analyzing 60 RSA couples and 60 controls ${ }^{[89]}$ and the second one analyzing the outcome of IVF procedures which found an increase dfrequency of allele HLA-G*01:03:01 in the cases of implantation failures. This story was interestingly refined in 2012, with the idea of a sex-dependent increased risk, when the mother was $+14 \mathrm{bp} /+14$ bp homozygote and presented with HLA Class II alleles restricting HY immunity. In this case, at the second pregnancy in the case of a boy child, there was a significant decrease in birth weight and an increased risk of miscarriage. ${ }^{[00]}$ Most explanations about this influence of the Ins/Del on pregnancy rely on the idea of differential stability of the mRNA encoding HLA-G and decreasing its concentration. Therefore, HLA-G expression level also appears as an important factor, an idea illustrated by the study of Ober and coworkers in 2003, associating HLA-G polymorphisms and recurrent pregnancy loss unambiguously. ${ }^{\left[{ }^{11]}\right.} \mathrm{In}$ this study, the analysis of the novel variant minus $725 \mathrm{C} / \mathrm{G}$ in the HLA-G promoter uncovered an association with miscarriage (OR: 2.76, 95\% CI: 1.08-7.09; $p=0.035$ ). Interestingly, the $\mathrm{G}$ generates a $\mathrm{CpG}$ site that is methylated, suggesting a possible epigenetic effect in the mechanisms of recurrent pregnancy loss, and substantiates the idea of potential impact of DNA methylation in reproduction disorders. ${ }^{[92]}$ Recently, and concurrent with this idea, more mechanistic experiments were carried out on trophoblast from first-trimester placentas of voluntarily terminated pregnancies. Immunotolerogenic treatments applied to the cells (dexamethasone, hydrocortisone) were able to modulate HLA-G expression positively, but the basal level of HLA-G was systematically lower in RSA patients. ${ }^{[93]}$

Since HLA is a relatively small chromosome region ( $<3 \mathrm{Mbp}$ ), LD between Class I and Class II can be expected and was indeed shown, for instance, in the locus encompassing the three Class II DRB $1 * 03-\mathrm{DQA} 1 * 05-\mathrm{DQB} 1 * 02$, on the one hand and the Class I G*01010 2 in the other hand $G^{*} 010102$ is the HLA-G haplotype that encompasses the 14-bp sequence 
variant ${ }^{[94]}$ This result could put forward the idea that only one of these genes is actually modulating implantation success, according to the alleles displayed by the patient.

A possible member of the dialog between HLA-G (either soluble or presented by trophoblasts) and uterine natural killer (NK) cells (which are major actors of vasculogenesis in pregnancy) is the KIR family. A genetic study showed, however, that the KIR repertoire was not different between controls and patients, albeit the KIR2DL4 genotypes differed significantly $(p=0.03) .{ }^{[95]}$

\section{Bad adjustments of the cytokinic dialog}

Immunity depends strongly on the presence of circulating molecules secreted by the different lymphocyte families. An over-simplistic vision of T cells is the idea of the existence of a tolerogenic versus aggressive balance, materialized as Th1 [inflammatory, secreting, for instance, interleukin (IL)-2 and interferon-gamma (INFy)] and Th2 (tolerogenic, secreting, for instance, IL-4, IL-5, IL-6, IL-10, and IL-13). Pregnancy was appreciated as a process where Th2 lymphocytes were overpowering Th1 lymphocytes. This prompted geneticists to find associations between cytokine-encoding genes and pregnancy loss.

\section{TH2 pathway}

IL-10 polymorphisms were evaluated to this respect as early as in 2001, ${ }^{[96]}$ but failed to pinpoint links between a $\mathrm{G}>\mathrm{A}$ polymorphism in the promoter $(-1082)$ and a risk of RSA for a population of 38 Finnish patients and 131 ethnically matched controls. A more systematic study of the IL-10 gene promoter analyzed together $-592 \mathrm{C} / \mathrm{A}, 819 \mathrm{C} / \mathrm{T}$, and $-1082 \mathrm{~A} / \mathrm{G}$ in strong $\mathrm{LD}$, in $350 \mathrm{RSA}$ cases and 200 controls, ${ }^{[97]}$ showing that the $-592 \mathrm{~A} / 819 \mathrm{~T} / 1082 \mathrm{~A}$ haplotype was more frequent in cases than in controls (OR: 4.01, 95\% CI: 1.83-7.95). To note, some negative studies (absence of genetic association found) can result from insufficient polymorphism of the SNP analyzed. For instance, for IL-10, Warren and coworkers reported on the comparison between the $-1082 \mathrm{~A} / \mathrm{G}$ variant and a microsatellite present in the promoter of IL-10, and could associate microsatellite alleles but not the SNP to cervical insufficiency, a cause of late miscarriage.

IL-6 variants were studied in RSA versus control patients unsuccessfully in 2003. ${ }^{[98]}$ However, this study was contradicted by Saijo and coworkers who discovered a protector effect of GG genotypes at the $-634 \mathrm{C}-->\mathrm{G}$ promoter polymorphism of IL-6 in the Japanese population. ${ }^{[99]}$ This association was confirmed in a Chinese sample of $162 \mathrm{RSA}$ patients and 156 controls. ${ }^{[100]}$ The same study did not find significant differences in IL-1 $\beta-31 \mathrm{~T},-511 \mathrm{~T}$, and $+3954 \mathrm{~T}$ between RSA patients and controls.

Interleukin 1 receptor antagonist (IL1RA; an immunomodulator encoded by the ILRN gene) alleles were also suggested as at risk for RSA ${ }^{[101]}$ with strong OR values for the effect of a specific allele, *2 (OR: 7.4, CI: 2.9-10.8). Consistent with the idea of an effect of this gene, a study comparing 37 Finnish women with RSA and 800 donors showed an increased frequency of a rare allele (IL1RN*3, OR: 5.6, 95\% CI: 1.5-19.0; $p=0.006) .{ }^{[102]}$ However, negative studies for IL1RN were also reported in various populations. ${ }^{[103-105]}$ IL1R1 (the receptor of IL-1 with Th1 effects) variants were also devoid of significant effects in a 2011 study. ${ }^{[106]}$

Always in the Th2 cascade, Il-4 was unsuccessfully explored in 2004 in a Japanese population through genotyping a specific number of repeat variations in a variable number tandem repeat (VNTR) polymorphism. ${ }^{[107]}$

\section{TH1 pathway}

In 2001, Reid and coworkers assessed TNF and IL1B alleles as risk factors for RSA, and did find a trend for association with a TNF variant. ${ }^{[108]}$ Il1RB was also studied for an exon 5 polymorphism $(+3953)$, while the serum levels were followed in parallel in 131 RSA patients and 68 controls, and no significant difference could be found. ${ }^{[109]}$ Later, the same group studied a $\mathrm{C} / \mathrm{T}$ polymorphism in the IL1B promoter (-511), together with M235T of AGT (SERPINA8) and Glu298Asp of eNOS (NOS3), which was unsuccessful again. However, Wang and coworkers identified IL1B -31T and IL1B -511C to be associated with a history of RSA in two cohorts totaling 262 RPL and 144 controls. ${ }^{[110]}$ This latter study also showed that trophoblasts treated by peripheral blood mononuclear cells (PBMC) of patients harboring the IL1B $-511 \mathrm{C}$ variant presented an

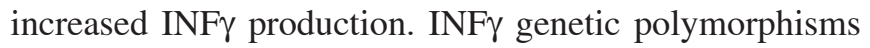
may also be directly involved as suggested by an Argentine study based upon 41 RSA and 54 control women. The authors analyzed variants of INF $\gamma, \mathrm{TNF} \alpha$, IL-6, IL-10, and transforming growth factor-beta (TGF $\beta$ ), and found an association between INF $874 \mathrm{~A} \rightarrow \mathrm{T}$ and RSA. Another study analyzed together, though unsuccessfully, the allelic distribution of Il-10 $(-1082 \mathrm{G}>\mathrm{A}), \mathrm{TNF} \alpha(-308 \mathrm{G}>\mathrm{A})$, and INFy $(874 \mathrm{~T}>\mathrm{A})$ alleles in a group of 43 patients and 73 controls of Caucasian ethnic background. ${ }^{[111]} \mathrm{TNF} \alpha(-308 \mathrm{G} / \mathrm{A})$ was, nevertheless, found to be significantly associated with RSA in a sample of Saudi women (65 cases vs 65 controls), although the same study failed to put forward associations with Il-6 and Il-10 polymorphisms. ${ }^{[112]}$

Amongst the proinflammatory cytokines, Il-21 variants were recently evaluated through genotyping a four SNP haplotype (rs9992580/rs4833837/rs2055979/rs13143866) on $235 \mathrm{RM}$ and 235 controls, and strong risk and protective haplotypes could be identified, such as G-A-A-A (OR: 4.02) and T-G-C-G (OR: 0.09), respectively. ${ }^{[113]}$ Since these haplotypes were present in $11.7 \%$ of the patients and $18.1 \%$ of the controls, they are not devoid of clinical interest. 


\section{Cytokines and immune cells dialog}

Links between interleukin signaling and the immune system are numerous. For instance, Il-12 and IL-18 are involved in uterine vascular development through the regulation of uterine NK cells. ${ }^{[114,115]}$ Promoter gene polymorphisms were analyzed for these factors in $125 \mathrm{RSA}$ cases and 136 controls $^{[116]}$ and did not demonstrate any significant association. However, a more recent study of 282 patients and 283 controls from Saudi Arabia on Il-18 promoter haplotypes reconstructed from genotyping four SNPs (rs1946519/rs187238/rs360718/rs360717) showed several haplotypes associated with reduced IL-18 levels and increase RSA risk. ${ }^{[117]}$ A more recent study extended to a Tunisian population the analysis of the same haplotype of four SNPs of Il-18 [-656C/A (rs1946519), -137G/C (rs187238), -119A/C (rs360718), and-105G/A (rs360717)]. ${ }^{[118]} \mathrm{A}-\mathrm{G}-\mathrm{A}-\mathrm{A}$ and C-G-A-A were associated with an increased risk of RPL (OR: 20.73 and 5.23, respectively), and C-G-A-G conferred a protection (OR: 0.29). Overall, these allelic combinations are found in $54 \%$ of the controls and $35 \%$ of the patients, which give them an important potential predictive value.

\section{Contribution of meta-analyses}

Overall, meta-analyses may help to clarify the issues of the impact of cytokine polymorphism and RSA, such as that of Bombell and McGuire, ${ }^{[119]}$ which evaluated studies on TNF $, I F N \gamma, I L 1 B, I I-6$, and $I L-10$ and concluded that IL-1B (-31T, at risk, OR: 2.12, CI: 1.04-4.33, from two studies) and IL-6 (-634G, OR: 0.22, 95\% CI: 0.09-0.57, but from one study only) had significant effects. In 2009, another meta-analysis concluded on the effect of the IL-10 genotype ${ }^{[120]} \mathrm{A}$ report combining experiments and meta-analyses of ILIB and ILIRN VNTR on a sample of Indian women did not find the association of variants of these genes with RSA. ${ }^{[121]} \mathrm{A}$ similar meta-analysis concluded the absence of significant effect of IL-6 (rs1800795) and IFN $\gamma$ (rs2430561), but comforted the idea of an association of $I L-10-1082 \mathrm{~A} / \mathrm{G}$ with the risk of RSA (rs1800896).

\section{Thrombophilic disorders}

There is an interesting and well-documented literature on the links between pregnancy loss and vascular diseases of pregnancy, particularly preeclampsia. Preeclampsia is a major disease of pregnancy, characterized by a gestational increase of maternal blood pressure and proteinuria. ${ }^{[122,123]}$ The etiology of preeclampsia remains largely unknown; however, a possible scenario is that in its genetic forms, alterations of the coagulation cascades could be a cornerstone of the disease. Collectively, defects leading to increased coagulation can be assimilated to thrombophilia (also called hypercoagulopathy, an abnormal increase in the propensity of the blood to clot). The coagulation cascade is a complex series of biological events that ought to be tightly controlled [Figure 2]. At the center of this cascade is thrombin (or coagulation factor II, F2), an enzyme able to convert fibrinogen into fibrin, the major constituent of the blood clot. Prothrombin, the precursor of thrombin, is cleaved and thus activated through the action of coagulation factor X (F10). Despite commonalities in coagulation disorders between preeclampsia and RSA, specific genetic anomalies have rarely been found in common between the two disorders, ${ }^{[124]}$ with the possible exception of angiotensin converting enzyme (ACE). In this gene, there is a well-documented insertion/deletion polymorphism (I/D) for which a recent meta-analysis concluded that there was a significant association of the $\mathrm{D}$ allele with recurrent miscarriage. ${ }^{[125]}$ In this analysis, 11 studies with 3357 individuals were analyzed. It led to the most significant discrepancy (DD vs II, homozygote model) and the relative risk was estimated at 1.81 (CI: $1.29-2.66 ; p=0.003)$. ACE D allele was also associated with preeclampsia (in a recent study ${ }^{[126]}$ ).

Overall, the subject of a genetic basis for recurrent pregnancy loss has been strongly associated with thrombophilic disorders, with major scientific contributions. ${ }^{[127]}$ This early study was probably the first to systematically analyze polymorphisms located in FV Leiden (F5), MTHFR, F2 (prothrombin), on a limited number of patients (67) and controls (232). In this seminal paper from the group of Irene Cetin, FVL and prothrombin mutations were found to be associated with a triple risk of pregnancy loss. Overall, the existence of a thrombophilic state seems a recurrent issue in RSA, as reviewed several times. ${ }^{[128-130]}$ Following these early discoveries, thrombophilia appeared as a general risk factor for pregnancy; logically, there have been several studies throughout the world, aiming at identifying polymorphisms in coagulation cascade factors encoding genes,

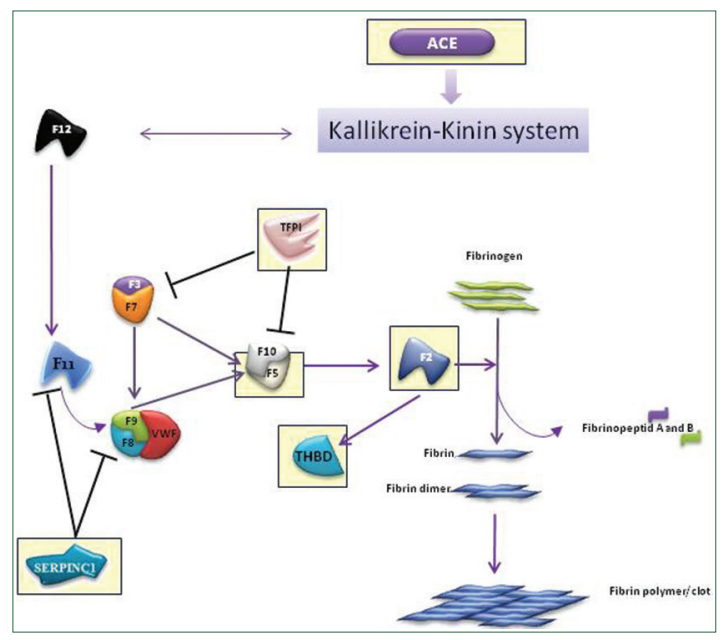

Figure 2: A simplified picture of the coagulation cascade. Genes that were mainly studied for their putative relation with RSA are represented in yellow boxes. 
in the context of recurrent miscarriage. Recently, Cao and coworkers carried out an extensive analysis of factors known to be involved in thrombophilia. ${ }^{[131]}$ They genotyped six polymorphisms in SERPINC1 (G786A), THBD (C1418T), TFPI(T-33C), FVL (G1628A), F2 (prothrombin, A19911G), and ANXA5 (G76A) using mass array spectrometry. This screen allowed identifying a significant effect only of thrombomodulin (THBD) from 94 cases and 169 controls. Interestingly, a large part of the genes studied were common to those of another study from Brazil. ${ }^{[132]}$ The latter article focused upon 117 RSA and 264 control patients, who were analyzed for protein C (PROC), at two SNPs (A2418G and C2405T), SERPINC1 (G786A, common to the previous study), THBD (C1418T, common to the previous study), and TFPI (T-287C, C-399T, and T-33C, common to the previous study), FVL (G1691A), and F2 (G20210A); therefore, five genes and three SNPs were common to both studies. Univariate logistic regression revealed an effect of SERPINC1 and TFPI variants only. The $P$ value for THBD was estimated at 0.661 , and did not even reveal a trend. It is interesting to note, however, that the T-33C variant, common to both studies was not significant in any of them. In the study of Cao, SERPINC1 did not display any trend as well. Therefore, there are clear discrepancies between the two studies for THBD and SERPINC1. Analyzing these two situations may, nevertheless, be illustrative of specific pitfalls in this type of association studies, the major one certainly being the ethnic origin of the patients: Chinese in one case, Brazilian and multiethnic in the other. This leads to strong discrepancies in the basic allelic frequencies of each of the common SNPs in the two studies [Table 1]. In this table, the alleles that were significantly different in one of the populations are marked in gray. This type of analysis

Table 1: Rare allele frequencies in two populations studied for RPL in the context of coagulation cascades

\begin{tabular}{lccc}
\hline & $\begin{array}{c}\text { Cao (2013) } \\
\text { Chinese }\end{array}$ & $\begin{array}{c}\text { Guerra-Shinohara } \\
(2012) \text { Brazilian }\end{array}$ & $p$ value \\
\hline SERPINC1 (G786A) & & & \\
$\quad$ Cases & 0.298 & 0.137 & $5.1410^{-5}$ \\
$\quad$ Controls & 0.311 & 0.087 & $3.9710^{-17}$ \\
THBD (C1418T) & & & \\
Cases & 0.293 & 0.132 & $4.9610^{-5}$ \\
Controls & 0.207 & 0.116 & $2.410^{-4}$ \\
TFPI (T-33C) & & & \\
Cases & 0.101 & 0.35 & $2.4110^{-9}$ \\
Controls & 0.107 & 0.324 & $2.5510^{-13}$ \\
\hline
\end{tabular}

The polymorphisms that were significantly different between controls and RSA patients are in bold. The $p$ values refer to significant statistical differences in allelic frequencies between the two populations assessed by a $\chi^{2}$ contingency test, independent of the potential effect in terms of pregnancy loss. Abbreviations: RPL: Recurrent pregnancy loss; SERPINC1: Serpin peptidase inhibitor, clade C (antithrombin), member 1; THBD: Thrombomodulin; TFPI: Tissue factor pathway inhibitor (lipoprotein-associated coagulation inhibitor) demonstrates highly significant discrepancies in the allelic frequencies between the two populations, as well as in cases and in controls.

\section{Whole genome approaches}

In terms of genetic determinism, the novel existing tools of genome wide association studies have recently allowed to identify genomic regions putatively encompassing genes involved in pregnancy success or pregnancy loss. However, so far, only two papers have been published dealing with such approaches. ${ }^{[133,134]}$ The premises of the latter study were provided by the observation of an increased risk of miscarriage in sisters sharing identical HLA variants. ${ }^{[58,135]}$ This is consistent with the increased risk of recurrent pregnancy loss exhibited by patients homozygous for the 14-bp insertion in the $8^{\text {th }}$ exon of HLA-G, as previously described. The study of 2011 confirmed the increased risk of recurrent miscarriage in siblings by analyzing 244 patients and 381 full siblings, of whom 23 had more than two miscarriages and three had two siblings with more than two miscarriages. The average risk of miscarriage in the control population was almost stable (10-15\%) between 15 and 32 years of maternal age, rising steeply after this age. But at any age, the risk was between 1.5- and 2-fold higher in the siblings than in the reference population (25.3 vs $13.1 \%$ ). By a genetic study using only 30 small nuclear families and 20,000 SNPs, suggestive linkages on subpopulations could be detected for SNPs in the genes FHIT (3p14.2), FAM154A (9p22.1), PDE2A (11q13.4), and GRIK2 (6q16.3) [Logarithm of the Odds (LOD) scores were between 2.5 and 3]. The other genome wide study published in 2010 by $\mathrm{Li}$ and coworkers identified three regions $(6 \mathrm{q} 27,9 \mathrm{q} 33.1$, and Xp22.1) that were not the same. ${ }^{[133]}$ In fact, again, the dissimilar origin of the population under scrutiny (Han Chinese) can be one of the causes of this phenomenon. Also, it was a pilot study performed on a very limited number of samples, with medium marker resolution (430 microsatellites). To the best of our knowledge, a high-density SNP analysis (with 250,000 or 500,000 SNPs) has not been performed yet, while such an analysis could improve the detection.

\section{Conclusions}

As shown before, the genetic study of pregnancy loss focused overall on a limited number of genes, which have been analyzed in numerous human populations. Following these observations, two hypotheses can be proposed: either (1) The major genes have already been found and duly studied and they explain much of the genetic bases of RSA or, on the contrary, (2) this phenotype is so complex that many genes with small effects can cause the disease, and the systematic study of some of them results from a very par- 
tial understanding of the causes underlying RSA. One such example is methylene tetrahydrofolate reductase (MTHFR). This enzyme, which is ubiquitously expressed, is responsible for the synthesis of 5-methyltetrahydrofolate. This molecule is the main methyl donor allowing conversion of homocysteine to methionine. In 1997, a Dutch team decided to study the $677 \mathrm{C} \rightarrow \mathrm{T}$ mutation, shown as a risk factor for coronary artery disease in particular. ${ }^{[136]}$ This study, published in The Lancet ${ }^{[137]}$ compared 197 patients who suffered from two or more consecutive miscarriages, with 113 matched controls and with a larger population of 1250 women. The author concluded that the 677 TT genotype was associated with a $~ 2-3$ fold increased risk of recurrent miscarriage. Following this study, 39 other articles dealing with MTHFR and RPL can be found in Pubmed, up to the year 2013, amongst which one is a recent meta-analysis, ${ }^{[131]}$ combining $677 \mathrm{C} \rightarrow \mathrm{T}$ with another polymorphism (A1298C). This last work focused on 3559 cases and 5097 controls and concluded that the $\mathrm{T}$ allele had a mod erate negative effect $(\mathrm{CT}+\mathrm{TT}$ genotypes, OR: $1.68,95 \%$ CI: $1.32-2.13 ; p<0.0001)$, the effect being stronger in East Asian populations.

It is interesting to note that almost all the studies attempted to identify significant variants by genetically analyzing a limited range of individuals (almost always less than 300). This means that rare variants cannot be found despite a clear effect. An exception to this is the identification of the JAK2 V617F mutation when a huge sample of 3496 pairs of women was analyzed. ${ }^{[138]}$ With such a powerful structure, it was possible to detect a very significant increased risk of fetal loss but with low allelic frequencies of the V617F

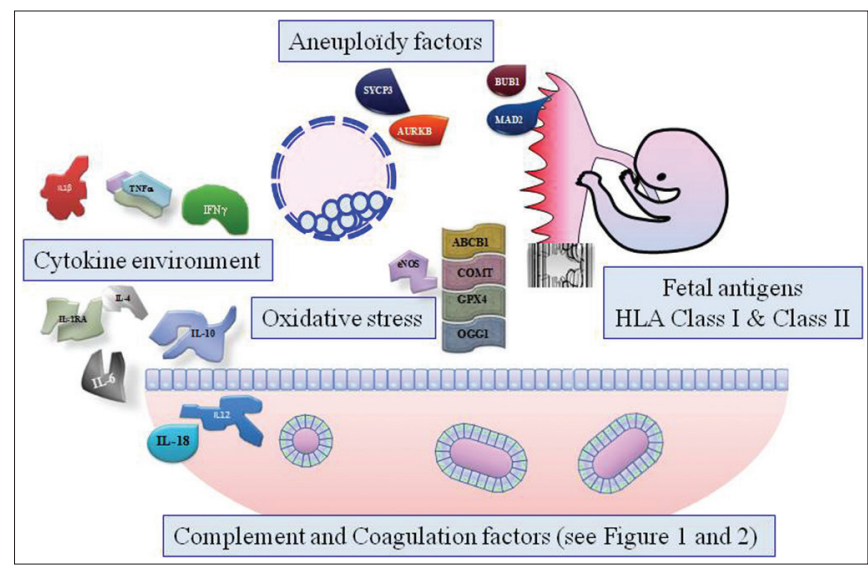

Figure 3: A simplified and not exhaustive graphic summary of the factors that may genetically influence pregnancy success. Several factors are more thoroughly described in the text. Even though the subject of the review is, strictly speaking, about pregnancy loss and, therefore, rather later stages than the blastocyst (presented in blue), early defects at this stage may allow implantation, but will trigger failure later on. Clearly, the propensity of the blastocyst to release free radicals, for instance, can foster defective immunomodulation, excessive inflammation leading to pregnancy loss, or to preeclampsia in less-severe cases. mutation $(1.06 \%$ in cases vs $0.20 \%$ in controls, OR: 4.63 , CI: 1.76-12.2). The risk was even higher in women with embryonic losses than in those with fetal loss. This observed effect of the low frequency of the risk variant could logically be very difficult to reproduce in smaller samples, while the biological interest of the study remains intact in terms of understanding the pathophysiology of RSA. Another possible approach to discover new genes is to use information gleaned from model species, following genome scans. This was recently performed in an interspecific recombinant congenic collection of mice followed during gestation by ultrasonography ${ }^{[139]}$ which recently allowed to propose human alkaline phosphatase polymorphisms to be associated with increased or decreased risk of pregnancy loss. ${ }^{[140]}$ In addition, various studies on mice demonstrated the importance of several pathways in this model species as well; this is the case for the complement system and its modulator genes. For instance, mouse models have provided a solid base of the importance of complement activation in successful pregnancies ( $\mathrm{C} 3$ being a pivotal molecule), as well as its regulation by alias CR1L (complement component ( $3 \mathrm{~b} / 4 \mathrm{~b}$ ) receptor 1-like), sometimes in relation with autoimmune diseases. ${ }^{[40,141-145]}$ Therefore, while the topic of the present review was human disease, it is clear that much can be understood mechanistically using animal models, especially rodents.

Different genetic cascade defects can result in pregnancy loss [Figure 3]. Very few studies on humans revealed functional insights on the events ending in pregnancy termination. Some pieces of this puzzle may definitely be missing today, but it would be of great importance to move to more mechanistic models to better understand the genetic bases of abortion.

\section{REFERENCES}

1. Kalousek DK. The effect of confined placental mosaicism on development of the human aneuploid conceptus. Birth Defects Orig Artic Ser 1993;29:39-51.

2. Liu J, Wang W, Sun X, Liu L, Jin H, Li M, et al. DNA microarray reveals that high proportions of human blastocysts from women of advanced maternal age are aneuploid and mosaic. Biol Reprod 2012;87:148.

3. Robinson WP, McFadden DE, Stephenson MD. The origin of abnormalities in recurrent aneuploidy/polyploidy. Am J Hum Genet 2001;69:1245-54.

4. Kurahashi H, Kogo H, Tsutsumi M, Inagaki H, Ohye T. Failure of homologous synapsis and sex-specific reproduction problems. Front Genet 2012;3:112.

5. Musacchio A, Salmon ED. The spindle-assembly checkpoint in space and time. Nat Rev Mol Cell Biol 2007;8:379-93.

6. Lopez-Carrasco A, Oltra S, Monfort S, Mayo S, Rosello M, Martinez F, et al. Mutation screening of AURKB and SYCP3 in patients with reproductive problems. Mol Hum Reprod 2013;19:102-8.

7. Shi Q, Hu M, Luo M, Liu Q, Jiang F, Zhang Y, et al. Reduced 
expression of Mad2 and Bub1 proteins is associated with spontaneous miscarriages. Mol Hum Reprod 2011;17:14-21.

8. Nath S, Moghe M, Chowdhury A, Godbole K, Godbole G, Doiphode $\mathrm{M}$, et al. Is germline transmission of MAD2 gene deletion associated with human fetal loss? Mol Hum Reprod 2012;18:554-62.

9. Caburet S, Arboleda VA, Llano E, Overbeek PA, Barbero JL, Oka K, et al. Mutant cohesin in premature ovarian failure. N Engl J Med 2014;370:943-9.

10. Bridge G, Monteiro R, Henderson S, Emuss V, Lagos D, Georgopoulou D, et al. The microRNA-30 family targets DLL4 to modulate endothelial cell behavior during angiogenesis. Blood 2012;120:5063-72.

11. Lyu SW, Song H, Yoon JA, Chin MU, Sung SR, Kim YS, et al. Transcriptional profiling with a pathway-oriented analysis in the placental villi of unexplained miscarriage. Placenta 2013;34:133-40.

12. Easton DF, Pooley KA, Dunning AM, Pharoah PD, Thompson D, Ballinger DG, et al. Genome-wide association study identifies novel breast cancer susceptibility loci. Nature 2007;447:1087-93.

13. Kirkinezos IG, Moraes CT Reactive oxygen species and mitochondrial diseases. Semin Cell Dev Biol 2001;12:449-57.

14. Gupta S, Agarwal A, Banerjee J, Alvarez JG. The role of oxidative stress in spontaneous abortion and recurrent pregnancy loss: A systematic review. Obstet Gynecol Surv 2007;62:335-47.

15. Ruder EH, Hartman TJ, Goldman MB. Impact of oxidative stress on female fertility. Curr Opin Obstet Gynecol 2009;21:219-22.

16. Khadzhieva MB, Lutcenko NN, Volodin IV, Morozova KV, Salnikova LE. Association of oxidative stress-related genes with idiopathic recurrent miscarriage. Free Radic Res 2014;48:534-41.

17. Tarry-Adkins JL, Martin-Gronert MS, Fernandez-Twinn DS, Hargreaves I, Alfaradhi MZ, Land JM, et al. Poor maternal nutrition followed by accelerated postnatal growth leads to alterations in DNA damage and repair, oxidative and nitrosative stress, and oxidative defense capacity in rat heart. FASEB J 2013;27:379-90.

18. Cotechini T, Komisarenko M, Sperou A, Macdonald-Goodfellow S, Adams MA, Graham CH. Inflammation in rat pregnancy inhibits spiral artery remodeling leading to fetal growth restriction and features of preeclampsia. J Exp Med 2014;211:165-79.

19. Myatt L. Review: Reactive oxygen and nitrogen species and functional adaptation of the placenta. Placenta 2010;31 Suppl: S66-9.

20. Su MT, Lin SH, Chen YC. Genetic association studies of angiogenesis- and vasoconstriction-related genes in women with recurrent pregnancy loss: A systematic review and meta-analysis. Hum Reprod Update 2011;17:803-12.

21. Tempfer C, Unfried G, Zeillinger R, Hefler L, Nagele F, Huber JC. Endothelial nitric oxide synthase gene polymorphism in women with idiopathic recurrent miscarriage. Hum Reprod 2001;16:1644-7.

22. Suryanarayana V, Rao L, Kanakavalli M, Padmalatha V, Deenadayal M, Singh L. Recurrent early pregnancy loss and endothelial nitric oxide synthase gene polymorphisms. Arch Gynecol Obstet 2006;274:119-24.

23. Fan W, Li SW, Wang Y. Association of genetic polymorphisms in endothelial nitric oxide synthase 3 gene with recurrent early spontaneous abortion. Zhonghua Yi Xue Yi Chuan Xue Za Zhi 2007;24:23-6.

24. Shin SJ, Lee HH, Cha SH, Kim JH, Shim SH, Choi DH, et al. Endothelial nitric oxide synthase gene polymorphisms (-786T $>C$, $4 \mathrm{a} 4 \mathrm{~b}, 894 \mathrm{G}>\mathrm{T})$ and haplotypes in Korean patients with recurrent spontaneous abortion. Eur J Obstet Gynecol Reprod Biol 2010;152:64-7.

25. Parveen F, Faridi RM, Das V, Tripathi G, Agrawal S. Genetic association of phase I and phase II detoxification genes with recurrent miscarriages among North Indian women. Mol Hum Reprod 2009;16:207-14.

26. Hefler LA, Tempfer CB, Bashford MT, Unfried G, Zeillinger R, Schneeberger C, et al. Polymorphisms of the angiotensinogen gene, the endothelial nitric oxide synthase gene, and the interleukin-1beta gene promoter in women with idiopathic recurrent miscarriage. Mol Hum Reprod 2002;8:95-100.

27. Buchholz T, Lohse P, Kosian E, Thaler CJ. Vasoconstrictively acting AT1R A1166C and NOS3 4/5 polymorphisms in recurrent spontaneous abortions (RSA). Am J Reprod Immunol 2004;51:323-8.

28. Makino A, Nakanishi T, Sugiura-Ogasawara M, Ozaki Y, Suzumori N, Suzumori K. No association of C677T methylenetetrahydrofolate reductase and an endothelial nitric oxide synthase polymorphism with recurrent pregnancy loss. Am J Reprod Immunol 2004;52:60-6.

29. Zammiti W, Mtiraoui N, Mahjoub T. Lack of consistent association between endothelial nitric oxide synthase gene polymorphisms, homocysteine levels and recurrent pregnancy loss in tunisian women. Am J Reprod Immunol 2008;59:139-45.

30. Karvela M, Papadopoulou S, Tsaliki E, Konstantakou E, Hatzaki A, Florentin-Arar L, et al. Endothelial nitric oxide synthase gene polymorphisms in recurrent spontaneous abortions. Arch Gynecol Obstet 2008;278:349-52.

31. Munafo MR, Flint J. Meta-analysis of genetic association studies. Trends Genet 2004;20:439-44.

32. Bonney EA, Matzinger $P$. The maternal immune system's interaction with circulating fetal cells. J Immunol 1997;158:40-7.

33. Chaouat G. Inflammation, NK cells and implantation: Friend and foe (the good, the bad and the ugly?): Replacing placental viviparity in an evolutionary perspective. J Reprod Immunol 2013;97:2-13.

34. Gill TJ $3^{\text {rd }}$. Role of the major histocompatibility complex region in reproduction, cancer, and autoimmunity. Am J Reprod Immunol $1996 ; 35: 211-5$

35. Coulam CB, Kaider BD, Kaider AS, Janowicz P, Roussev RG. Antiphospholipid antibodies associated with implantation failure after IVF/ET. J Assist Reprod Genet 1997;14:603-8.

36. Carp HJ, Selmi C, Shoenfeld Y. The autoimmune bases of infertility and pregnancy loss. J Autoimmun 2012;38:J266-274.

37. Shoenfeld Y, Carp HJ, Molina V, Blank M, Cervera R, Balasch J, et al. Autoantibodies and prediction of reproductive failure. Am J Reprod Immunol 2006;56:337-44.

38. Moravej A, Jeddi-Tehrani M, Salek-Moghaddam AR, Dokouhaki P, Ghods R, Rabbani H, et al. Evaluation of thyroglobulin expression in murine reproductive organs during pregnancy. Am J Reprod Immunol 2010;64:97-103

39. Salmon JE, Heuser C, Triebwasser M, Liszewski MK, Kavanagh D, Roumenina L, et al. Mutations in complement regulatory proteins predispose to preeclampsia: A genetic analysis of the PROMISSE cohort. PLoS Med 2011;8:e1001013.

40. Girardi G, Yarilin D, Thurman JM, Holers VM, Salmon JE. Complement activation induces dysregulation of angiogenic factors and causes fetal rejection and growth restriction. J Exp Med 2006;203:2165-75.

41. Galazios G, Papazoglou D, Tsikouras P, Kolios G. Vascular 
endothelial growth factor gene polymorphisms and pregnancy. J Matern Fetal Neonatal Med 2009;22:371-8.

42. Bouvier S, Cochery-Nouvellon E, Lavigne-Lissalde G, Mercier E, Fabbro-Peray P, Balducchi JP, et al. Comparative incidence of pregnancy outcomes in thrombophilia-positive women from the NOH-APS observational study. Blood 2014;123:414-21.

43. Fang CJ, Fremeaux-Bacchi V, Liszewski MK, Pianetti G, Noris M, Goodship TH, et al. Membrane cofactor protein mutations in atypical hemolytic uremic syndrome (aHUS), fatal Stx-HUS, C3 glomerulonephritis, and the HELLP syndrome. Blood 2008;111:624-32.

44. Risk JM, Flanagan BF, Johnson PM. Polymorphism of the human CD46 gene in normal individuals and in recurrent spontaneous abortion. Hum Immunol 1991;30:162-7.

45. Laitinen T, Lokki ML, Tulppala M, Ylikorkala O, Koskimies S. Tumour necrosis factor B gene polymorphism in relation to complotype in couples with spontaneous abortions and in control families. Scand J Immunol 1992;35:131-5.

46. Zutshi N, Gandhi M, Kaul P. CD46 polymorphism: A probable risk factor for recurrent spontaneous abortion in a northern Indian population. Natl Med J India 2010;23:85-7.

47. Mohlin FC, Mercier E, Fremeaux-Bacchi V, Liszewski MK, Atkinson JP, Gris JC, et al. Analysis of genes coding for CD46, $\mathrm{CD} 55$, and $\mathrm{C} 4 \mathrm{~b}$-binding protein in patients with idiopathic, recurrent, spontaneous pregnancy loss. Eur J Immunol 2013;43:1617-29.

48. Dausset J. The major histocompatibility complex in man. Science 1981;213:1469-74.

49. Faulk WP, Sanderson AR, Temple A. Distribution of MHC antigens in human placental chorionic villi. Transplant Proc 1977;9:1379-84.

50. Hunt JS, Orr HT. HLA and maternal-fetal recognition. FASEB J 1992;6:2344-8.

51. Redman CW, Bodmer JG, Bodmer WF, Beilin LJ, Bonnar J. HLA antigens in severe pre-eclampsia. Lancet 1978;2:397-9.

52. Takakuwa K, Higashino M, Ueda H, Yamada K, Asano K, Yasuda M, et al. Significant compatibility does not exist at the HLA-DQB gene locus in couples with unexplained recurrent abortions. Am J Reprod Immunol 1992;28:12-6.

53. Hataya I, Takakuwa K, Tanaka K. Human leukocyte antigen class II genotype in patients with recurrent fetal miscarriage who are positive for anticardiolipin antibody. Fertil Steril 1998;70:919-23.

54. Takakuwa K, Hataya I, Arakawa M, Kikuchi A, Higashino M, Yasuda M, et al. Possible susceptibility of the HLA-DPB $1 * 0402$ and HLA-DPB $1 * 04$ alleles to unexplained recurrent abortion: Analysis by means of polymerase chain reaction-restricted fragment length polymorphism method. Am J Reprod Immunol 1999;42:233-9.

55. Takakuwa K, Adachi H, Hataya I, Ishii K, Tamura M, Tanaka K. Molecular genetic studies of HLA-DRB1 alleles in patients with unexplained recurrent abortion in the Japanese population. Hum Reprod 2003;18:728-33.

56. Sagot P, Bignon J, Cesbron A, Cheneau ML, Boog G, Muller JY. Lack of evidence for a role of HLA-DP in unexplained recurrent spontaneous abortion. Transfus Clin Biol 1995;2:145-50.

57. Christiansen OB, Mathiesen O, Husth M, Jersild C, Grunnet N. Studies of RFLP-inferred HLA-DR-DQ haplotypes in Danish women with recurrent fetal losses. Tissue Antigens 1992;40:134-9.
58. Christiansen OB, Rasmussen KL, Jersild C, Grunnet N. HLA class II alleles confer susceptibility to recurrent fetal losses in Danish women. Tissue Antigens 1994;44:225-33.

59. Kruse C, Steffensen R, Varming K, Christiansen OB. A study of HLA-DR and -DQ alleles in 588 patients and 562 controls confirms that HLA-DRB $1 * 03$ is associated with recurrent miscarriage. Hum Reprod 2004;19:1215-21.

60. Laitinen T, Koskimies S, Westman P. Foeto-maternal compatibility in HLA-DR, -DQ, and -DP loci in Finnish couples suffering from recurrent spontaneous abortions. Eur J Immunogenet 1993;20:249-58.

61. Lin Q, Lu P, Wang X. Study on human leucocyte antigen-DQ region gene polymorphism in cases of habitual abortion with anticardiolipin antibody. Zhonghua Fu Chan Ke Za Zhi 2000;35:208-11.

62. Wang XP, Lin QD, Lu PH, Ma ZW, Zhao AM. Association of HLA-DQB1 coding region with unexplained recurrent spontaneous abortion. Chin Med J (Engl) 2004;117:492-7.

63. Zheng ML, Niu LY. Association of soluble human leukocyte antigen DQB1 with recurrent spontaneous abortion. Zhonghua Fu Chan Ke Za Zhi 2006;41:152-4.

64. Bompeixe EP, Carvalho Santos PS, Vargas RG, von Linsingen R, Zeck SC, Wowk PF, et al. HLA class II polymorphisms and recurrent spontaneous abortion in a Southern Brazilian cohort. Int J Immunogenet 2012;40:186-91.

65. Gonzalez A, Rebmann V, LeMaoult J, Horn PA, Carosella ED, Alegre E. The immunosuppressive molecule HLA-G and its clinical implications. Crit Rev Clin Lab Sci 2012;49:63-84.

66. Hsu P, Santner-Nanan B, Dahlstrom JE, Fadia M, Chandra A, Peek M, et al. Altered decidual DC-SIGN+antigen-presenting cells and impaired regulatory T-cell induction in preeclampsia. Am J Pathol 2012;181:2149-60

67. Nowak I, Malinowski A, Tchorzewski H, Barcz E, Wilczynski JR, Banasik M, et al. HLA-C C1C2 heterozygosity may protect women bearing the killer immunoglobulin-like receptor AA genotype from spontaneous abortion. J Reprod Immunol 2012;88:32-7.

68. Hiby SE, Walker JJ, O’Shaughnessy KM, Redman CW, Carrington M, Trowsdale J, et al. Combinations of maternal KIR and fetal HLA-C genes influence the risk of preeclampsia and reproductive success. J Exp Med 2004;200:957-65.

69. Kotze D, Kruger TF. HLA-G as a marker for embryo selection in assisted reproductive technology. Fertil Steril 2013;100:e44.

70. Karhukorpi J, Laitinen T, Tiilikainen AS. HLA-G polymorphism in Finnish couples with recurrent spontaneous miscarriage. Br J Obstet Gynaecol 1997;104:1212-4.

71. Yamashita T, Fujii T, Tokunaga K, Tadokoro K, Hamai Y, Miki A, et al. Analysis of human leukocyte antigen-G polymorphism including intron 4 in Japanese couples with habitual abortion. Am J Reprod Immunol 1999;41:159-63.

72. Hviid TV, Christiansen OB, Johansen JK, Hviid UR, Lundegaard C, Moller C, et al. Characterization of a new HLA-G allele encoding a nonconservative amino acid substitution in the alpha3 domain (exon 4) and its relevance to certain complications in pregnancy. Immunogenetics 2001;53:48-53.

73. Aldrich CL, Stephenson MD, Karrison T, Odem RR, Branch DW, Scott JR, et al. HLA-G genotypes and pregnancy outcome in couples with unexplained recurrent miscarriage. Mol Hum Reprod 2001;7:1167-72. 
74. Hviid TV, Hylenius S, Hoegh AM, Kruse C, Christiansen OB. HLA-G polymorphisms in couples with recurrent spontaneous abortions. Tissue Antigens 2002;60:122-32.

75. Hviid TV, Hylenius S, Lindhard A, Christiansen OB. Association between human leukocyte antigen-G genotype and success of in vitro fertilization and pregnancy outcome. Tissue Antigens 2004;64:66-9.

76. Tripathi P, Abbas A, Naik S, Agrawal S. Role of 14-bp deletion in the HLA-G gene in the maintenance of pregnancy. Tissue Antigens 2004;64:706-10.

77. Kano T, Mori T, Furudono M, Ishikawa H, Watanabe H, Kikkawa E, et al. Human leukocyte antigen may predict outcome of primary recurrent spontaneous abortion treated with paternal lymphocyte alloimmunization therapy. Am J Reprod Immunol 2007;58:383-7.

78. Yan WH, Fan LA, Yang JQ, Xu LD, Ge Y, Yao FJ. HLA-G polymorphism in a Chinese Han population with recurrent spontaneous abortion. Int J Immunogenet 2006;33:55-8.

79. Yan WH, Lin A, Chen XJ, Dai MZ, Gan LH, Zhou MY, et al. Association of the maternal 14-bp insertion polymorphism in the HLA-G gene in women with recurrent spontaneous abortions. Tissue Antigens 2006;68:521-3.

80. Sipak-Szmigiel O, Cybulski C, Lubinski J, Ronin-Walknowska E. HLA-G polymorphism in a Polish population and reproductive failure. Tissue Antigens 2008;71:67-71.

81. Sipak-Szmigiel O, Cybulski C, Wokolorczyk D, Lubinski J, Kurzawa R, Baczkowski T, et al. HLA-G polymorphism and in vitro fertilization failure in a Polish population. Tissue Antigens 2009;73:348-52.

82. Aruna M, Sirisha PV, Andal Bhaskar S, Tarakeswari S, Thangaraj K, Reddy BM. Role of 14-bp insertion/deletion polymorphism in HLA-G among Indian women with recurrent spontaneous abortions. Tissue Antigens 2011;77:131-5.

83. Jassem RM, Shani WS, Loisel DA, Sharief M, Billstrand C, Ober C. HLA-G polymorphisms and soluble HLA-G protein levels in women with recurrent pregnancy loss from Basrah province in Iraq. Hum Immunol 2012;73:811-7.

84. Xue S, Yang J, Yao F, Xu L, Fan L. Recurrent spontaneous abortions patients have more $-14 \mathrm{bp} /+14 \mathrm{bp}$ heterozygotes in the 3'UT region of the HLA-G gene in a Chinese Han population. Tissue Antigens 2007;69 Suppl 1:153-5.

85. Wang X, Jiang W, Zhang D. Association of 14-bp insertion/ deletion polymorphism of HLA-G gene with unexplained recurrent spontaneous abortion: A meta-analysis. Tissue Antigens 2013;81:108-15

86. Suryanarayana V, Rao L, Kanakavalli M, Padmalatha V, Raseswari T, Deenadayal M, et al. Association between novel HLA-G genotypes and risk of recurrent miscarriages: A case-control study in a South Indian population. Reprod Sci 2008;15:817-24.

87. Kolte AM, Steffensen R, Nielsen HS, Hviid TV, Christiansen OB. Study of the structure and impact of human leukocyte antigen (HLA)-G-A, HLA-G-B, and HLA-G-DRB1 haplotypes in families with recurrent miscarriage. Hum Immunol 2010;71:482-8.

88. Berger DS, Hogge WA, Barmada MM, Ferrell RE. Comprehensive analysis of HLA-G: Implications for recurrent spontaneous abortion. Reprod Sci 2010;17:331-8.

89. Vargas RG, Sarturi PR, Mattar SB, Bompeixe EP, Silva Jdos S, Pirri A, et al. Association of HLA-G alleles and 3' UTR 14 bp haplotypes with recurrent miscarriage in Brazilian couples. Hum Immunol 2011;72:479-85.
90. Christiansen OB, Kolte AM, Dahl M, Larsen EC, Steffensen R, Nielsen HS, et al. Maternal homozygocity for a 14 base pair insertion in exon 8 of the HLA-G gene and carriage of HLA class II alleles restricting $\mathrm{HY}$ immunity predispose to unexplained secondary recurrent miscarriage and low birth weight in children born to these patients. Hum Immunol 2012;73:699-705.

91. Ober C, Aldrich CL, Chervoneva I, Billstrand C, Rahimov F, Gray HL, et al. Variation in the HLA-G promoter region influences miscarriage rates. Am J Hum Genet 2003;72:1425-35.

92. Calicchio R, Doridot L, Miralles F, Mehats C, Vaiman D. DNA methylation, an epigenetic mode of gene expression regulation in reproductive science. Curr Pharm Des 2014;20:1726-50.

93. Akhter A, Faridi RM, Das V, Pandey A, Naik S, Agrawal S. In vitro up-regulation of HLA-G using dexamethasone and hydrocortisone in first-trimester trophoblast cells of women experiencing recurrent miscarriage. Tissue Antigens 2012;80:126-35.

94. Hviid TV, Christiansen OB. Linkage disequilibrium between human leukocyte antigen (HLA) class II and HLA-G--possible implications for human reproduction and autoimmune disease. Hum Immunol 2005;66:688-99.

95. Witt CS, Goodridge J, Gerbase-Delima MG, Daher S, Christiansen FT. Maternal KIR repertoire is not associated with recurrent spontaneous abortion. Hum Reprod 2004;19:2653-7.

96. Karhukorpi J, Laitinen T, Karttunen R, Tiilikainen AS. The functionally important IL-10 promoter polymorphism (-1082G-->A) is not a major genetic regulator in recurrent spontaneous abortions. Mol Hum Reprod 2001;7:201-3.

97. Zammiti W, Mtiraoui N, Cochery-Nouvellon E, Mahjoub T, Almawi WY, Gris JC. Association of -592C/A, -819C/T and -1082A/ $\mathrm{G}$ interleukin-10 promoter polymorphisms with idiopathic recurrent spontaneous abortion. Mol Hum Reprod 2006;12:771-6.

98. Unfried G, Bocskor S, Endler G, Nagele F, Huber JC, Tempfer CB. A polymorphism of the interleukin-6 gene promoter and idiopathic recurrent miscarriage. Hum Reprod 2003;18:267-70.

99. Saijo Y, Sata F, Yamada H, Kondo T, Kato EH, Kishi R. Single nucleotide polymorphisms in the promoter region of the interleukin-6 gene and the risk of recurrent pregnancy loss in Japanese women. Fertil Steril 2004;81:374-8.

100. Ma X, Xu LJ, Wang J, Xian MM, Liu M. Association of IL-1beta and IL-6 gene polymorphisms with recurrent spontaneous abortion in a Chinese Han population. Int J Immunogenet 2011;39:15-9.

101. Unfried G, Tempfer C, Schneeberger C, Widmar B, Nagele F, Huber JC. Interleukin 1 receptor antagonist polymorphism in women with idiopathic recurrent miscarriage. Fertil Steril 2001;75:683-7.

102. Karhukorpi J, Laitinen T, Kivela H, Tiilikainen A, Hurme M. IL-1 receptor antagonist gene polymorphism in recurrent spontaneous abortion. J Reprod Immunol 2003;58:61-7.

103. Linjawi S, Li TC, Laird S, Blakemore A. Interleukin-1 receptor antagonist and interleukin-1 beta polymorphisms in women with recurrent miscarriage. Fertil Steril 2005;83:1549-52.

104. Levrant S, Coulam CB, Jeyendran RS. Interleukin 1 receptor antagonist gene polymorphisms are not risk factors for recurrent pregnancy loss: Evaluation of couples. Am J Reprod Immunol 2008;60:224-8.

105. Dai MZ, Pan YQ, Xu DP, Chen XJ, Qian RJ, Chen DH, et al. IL-1 receptor antagonist gene polymorphism in idiopathic recurrent spontaneous abortion in a Chinese Han population. Int J Immunogenet 2010;37:393-6 
106. Traina E, Daher S, Moron AF, Sun SY, Franchim CS, Mattar R. Polymorphisms in VEGF, progesterone receptor and IL-1 receptor genes in women with recurrent spontaneous abortion. J Reprod Immunol 2010;88:53-7.

107. Saijo Y, Sata F, Yamada H, Konodo T, Kato EH, Kataoka S, et al. Interleukin-4 gene polymorphism is not involved in the risk of recurrent pregnancy loss. Am J Reprod Immunol 2004;52:143-6.

108. Reid JG, Simpson NA, Walker RG, Economidou O, Shillito J, Gooi HC, et al. The carriage of pro-inflammatory cytokine gene polymorphisms in recurrent pregnancy loss. Am J Reprod Immunol 2001;45:35-40.

109. Hefler LA, Tempfer CB, Unfried G, Schneeberger C, Lessl K, Nagele $\mathrm{F}$, et al. A polymorphism of the interleukin-1beta gene and idiopathic recurrent miscarriage. Fertil Steril 2001;76:377-9.

110. Wang ZC, Yunis EJ, De los Santos MJ, Xiao L, Anderson DJ, Hill JA. $\mathrm{T}$ helper 1-type immunity to trophoblast antigens in women with a history of recurrent pregnancy loss is associated with polymorphism of the IL1B promoter region. Genes Immun 2002;3:38-42.

111. Babbage SJ, Arkwright PD, Vince GS, Perrey C, Pravica V, Quenby S, et al. Cytokine promoter gene polymorphisms and idiopathic recurrent pregnancy loss. J Reprod Immunol 2001;51:21-7.

112. Alkhuriji AF, Alhimaidi AR, Babay ZA, Wary AS. The relationship between cytokine gene polymorphism and unexplained recurrent spontaneous abortion in Saudi females. Saudi Med J 2013;34:484-9.

113. Messaoudi S, Al-Khateeb GM, Dendana M, Sater MS, Jazia KB, Nouira M, et al. (2011) Genetic variations in the interleukin-21 gene and the risk of recurrent idiopathic spontaneous miscarriage. Eur Cytokine Netw 2013;22:123-6.

114. Le Bouteiller P, Tabiasco J. Killers become builders during pregnancy. Nat Med 2006;12:991-2.

115. Hanna J, Goldman-Wohl D, Hamani Y, Avraham I, Greenfield C, Natanson-Yaron S, et al. Decidual NK cells regulate key developmental processes at the human fetal-maternal interface. Nat Med 2006;12:1065-74.

116. Ostojic S, Volk M, Medica I, Kapovic M, Meden-Vrtovec H, Peterlin B. Polymorphisms in the interleukin-12/18 genes and recurrent spontaneous abortion. Am J Reprod Immunol 2007;58:403-8.

117. Al-Khateeb GM, Sater MS, Finan RR, Mustafa FE, Al-Busaidi AS, Al-Sulaiti MA, et al. Analysis of interleukin-18 promoter polymorphisms and changes in interleukin-18 serum levels underscores the involvement of interleukin-18 in recurrent spontaneous miscarriage. Fertil Steril 2011;96:921-6.

118. Messaoudi S, Dandana M, Magdoud K, Meddeb S, Ben Slama N, Hizem S, et al. Interleukin-18 promoter polymorphisms and risk of idiopathic recurrent pregnancy loss in a Tunisian population. J Reprod Immunol 2012;93:109-13.

119. Bombell S, McGuire W. Cytokine polymorphisms in women with recurrent pregnancy loss: Meta-analysis. Aust N Z J Obstet Gynaecol 2008;48:147-54.

120. Medica I, Ostojic S, Pereza N, Kastrin A, Peterlin B. Association between genetic polymorphisms in cytokine genes and recurrent miscarriage--a meta-analysis. Reprod Biomed Online 2009;19:406-14.

121. Agrawal S, Parveen F, Faridi RM, Prakash S. Interleukin-1 gene cluster variants and recurrent pregnancy loss among North Indian women: Retrospective study and meta-analysis. Reprod Biomed Online 2012;24:342-51.
122. Sibai BM. Thrombophilia and severe preeclampsia: Time to screen and treat in future pregnancies? Hypertension 2005;46:1252-3.

123. Redman CW, Sargent IL. Latest advances in understanding preeclampsia. Science 2005;308:1592-4.

124. Davenport WB, Kutteh WH. Inherited thrombophilias and adverse pregnancy outcomes: A review of screening patterns and recommendations. Obstet Gynecol Clin North Am 2014;41:133-44.

125. Wang Z, Wang P, Wang X, He X, Xu D, Hu J, et al. Significant association between angiotensin-converting enzyme gene insertion/deletion polymorphism and risk of recurrent miscarriage: A systematic review and meta-analysis. Metabolism 2013;62:1227-38.

126. Rahimi Z, Aghaei A, Vaisi-Raygani A. AT2R -1332 G: A polymorphism and its interaction with AT1R 1166 A: C, ACE I/D and MMP-9 -1562 C: T polymorphisms: Risk factors for susceptibility to preeclampsia. Gene 2014;538:176-81.

127. Martinelli I, Taioli E, Cetin I, Marinoni A, Gerosa S, Villa MV, et al. Mutations in coagulation factors in women with unexplained late fetal loss. N Engl J Med 2000;343:1015-8.

128. Napoli C, Witztum JL, de Nigris F, Palumbo G, D’Armiento FP, Palinski W. Intracranial arteries of human fetuses are more resistant to hypercholesterolemia-induced fatty streak formation than extracranial arteries. Circulation 1999;99:2003-10.

129. Jasper MJ, Tremellen KP, Robertson SA. Primary unexplained infertility is associated with reduced expression of the T-regulatory cell transcription factor Foxp3 in endometrial tissue. Mol Hum Reprod 2006;12:301-8.

130. Rey E, Kahn SR, David M, Shrier I. Thrombophilic disorders and fetal loss: A meta-analysis. Lancet 2003;361:901-8.

131. Cao J, Cai J, Huang D, Han Q, Yang Q, Li T, et al. miR-335 represents an invasion suppressor gene in ovarian cancer by targeting Bcl-w. Oncol Rep 2013;30:701-6.

132. Guerra-Shinohara EM, Bertinato JF, Tosin Bueno C, Cordeiro da Silva K, Burlacchini de Carvalho MH, Pulcineli Vieira Francisco R, et al. Polymorphisms in antithrombin and in tissue factor pathway inhibitor genes are associated with recurrent pregnancy loss. Thromb Haemost 2013;108:693-700.

133. Li W, Zeng Chan W, Cui X, Xiao Feng L, Mao Sheng Y. Genome-wide screening for risk Loci of idiopathic recurrent miscarriage in a Han Chinese population: A pilot study. Reprod Sci 2010;17:578-84.

134. Kolte AM, Nielsen HS, Moltke I, Degn B, Pedersen B, Sunde L, et al. A genome-wide scan in affected sibling pairs with idiopathic recurrent miscarriage suggests genetic linkage. Mol Hum Reprod 2011;17:379-85.

135. Christiansen OB, Riisom K, Lauritsen JG, Grunnet N, Jersild C. Association of maternal HLA haplotypes with recurrent spontaneous abortions. Tissue Antigens 1989;34:190-9.

136. Kluijtmans LA, Kastelein JJ, Lindemans J, Boers GH, Heil SG, Bruschke AV, et al. Thermolabile methylenetetrahydrofolate reductase in coronary artery disease. Circulation 1997;96:2573-7.

137. Nelen WL, van der Molen EF, Blom HJ, Heil SG, Steegers EA, Eskes TK. Recurrent early pregnancy loss and genetic-related disturbances in folate and homocysteine metabolism. Br J Hosp Med 1997;58:511-3. 
138. Mercier E, Lissalde-Lavigne G, Gris JC. JAK2 V617F mutation in unexplained loss of first pregnancy. N Engl J Med 2007;357:1984-5.

139. Laissue P, Burgio G, l'Hote D, Renault G, Marchiol-Fournigault C, Fradelizi D, et al. Identification of Quantitative Trait Loci responsible for embryonic lethality in mice assessed by ultrasonography. Int $\mathrm{J}$ Dev Biol 2009;53:623-9.

140. Vatin M, Bouvier S, Bellazi L, Montagutelli X, Laissue P, Ziyyat A, et al. Polymorphisms of human placental alkaline phosphatase are associated with in vitro fertilization success and recurrent pregnancy loss. Am J Pathol 2014;184:362-8.

141. Cohen D, Buurma A, Goemaere NN, Girardi G, le Cessie S, Scherjon S, et al. Classical complement activation as a footprint for murine and human antiphospholipid antibody-induced fetal loss. J Pathol 2011;225:502-11.
142. Girardi G, Salmon JB. The role of complement in pregnancy and fetal loss. Autoimmunity 2003;36:19-26.

143. Wu X, Spitzer D, Mao D, Peng SL, Molina H, Atkinson JP. Membrane protein Crry maintains homeostasis of the complement system. J Immunol 2008;181:2732-40.

144. Pedroni SM, Gonzalez JM, Wade J, Jansen MA, Serio A, Marshall I, et al. Complement inhibition and statins prevent fetal brain cortical abnormalities in a mouse model of preterm birth. Biochim Biophys Acta 2014;1842:107-15.

145. Takeshita A, Kusakabe KT, Hiyama M, Kuniyoshi N, Kondo T, Kano K, et al. Dynamics and reproductive effects of complement factors in the spontaneous abortion model of $\mathrm{CBA} / \mathrm{JxDBA} / 2$ mice. Immunobiology 2014;219:385-91. 